\title{
Potential and limits of out-of-court rapid claims settlement - a law and economics analysis
}

Citation for published version (APA):

Faure, M. G., \& Weber, F. (2016). Potential and limits of out-of-court rapid claims settlement - a law and economics analysis. Journal of Environmental Law, 28(1), 125-150. https://doi.org/10.1093/jel/eqv031

Document status and date:

Published: 01/03/2016

DOI:

10.1093/jel/eqv031

Document Version:

Publisher's PDF, also known as Version of record

Document license:

Taverne

Please check the document version of this publication:

- A submitted manuscript is the version of the article upon submission and before peer-review. There can be important differences between the submitted version and the official published version of record.

People interested in the research are advised to contact the author for the final version of the publication, or visit the DOI to the publisher's website.

- The final author version and the galley proof are versions of the publication after peer review.

- The final published version features the final layout of the paper including the volume, issue and page numbers.

Link to publication

\footnotetext{
General rights rights.

- You may freely distribute the URL identifying the publication in the public portal. please follow below link for the End User Agreement:

www.umlib.nl/taverne-license

Take down policy

If you believe that this document breaches copyright please contact us at:

repository@maastrichtuniversity.nl

providing details and we will investigate your claim.
}

Copyright and moral rights for the publications made accessible in the public portal are retained by the authors and/or other copyright owners and it is a condition of accessing publications that users recognise and abide by the legal requirements associated with these

- Users may download and print one copy of any publication from the public portal for the purpose of private study or research.

- You may not further distribute the material or use it for any profit-making activity or commercial gain

If the publication is distributed under the terms of Article $25 \mathrm{fa}$ of the Dutch Copyright Act, indicated by the "Taverne" license above, 


\title{
Potential and Limits of Out-Of-Court Rapid Claims Settlement-A Law and Economics Analysis*
}

\author{
Michael Faure ${ }^{* *}$ and Franziska Weber***
}

\begin{abstract}
This article deals with compensation mechanisms for the aftermath of disasters. It claims that there is a necessity to speedily compensate victims of an accident, if this can prevent the occurrence of large societal follow-on damage. In reality this does not often happen. This article takes the entitlement to compensation as given, does not discuss substantive law matters regarding compensation, but deals with procedural aspects of how to actually get this compensation. The main obstacles to fast compensation may be found in lengthy mass litigation. Then again, civil litigation also entails economic advantages. There are law and economics arguments in favour of litigation versus alternative dispute resolution (ADR) solutions. After setting out the theoretical arguments, we discuss some American and European real-life examples of such rapid claims settlement mechanisms: the Gulf Coast Claims Facility (GCCF) and the Belgian compensation fund for technological accidents. The theoretical discussion, enriched by the illustration of the practical examples, will culminate in guidelines on how to set up a rapid claims settlement mechanism.

KEYWORD S : alternative dispute resolution, Gulf Coast Claim Facility, offshore pollution, civil litigation, environmental liability, compensation fund, liability insurance
\end{abstract}

\section{INTRODUCTION}

Catastrophes like the explosion on the offshore oil drilling rig Deepwater Horizon, and the oil spill it led to, call for rapid claims settlement procedures. How do victims obtain compensation in the aftermath of such disasters? A problem that has arisen with mass tort litigation is that the liability system and the accompanying civil procedure as a mechanism to allocate liability, have proven to be very costly and

* This piece builds upon Michael Faure and Franziska Weber, 'Towards a Rapid Claims Settlement Mechanism for Disasters?' in Kai Purnhagen and Peter Rott (eds), Varieties of European Economic Law and Regulation (Liber Amicorum for Hans Micklitz, Springer 2014) 735-56.

** University of Maastricht - Faculty of Law, Metro, Maastricht, the Netherlands; Erasmus University Rotterdam - Erasmus School of Law, Rotterdam, the Netherlands

*** University of Hamburg - Faculty of Law, Hamburg, Germany. (franziska.weber@uni-hamburg.de) 
time-consuming. Especially with disasters, where the numbers of victims (and thus plaintiffs) may be large. This is true for US litigation, ${ }^{1}$ but also in Europe. For example, in Belgium the explosion of a pipeline in Ghislenghien led to a lengthy criminal procedure. Since under Belgian law, civil suits cannot be handled as long as the criminal procedure has not been finalised, ${ }^{2}$ most of the victims only received compensation many years after the incident took place. The obstacles to rapid compensation are consequently a global concern, even if the precise procedures and contingencies may differ from country to country.

The case of oil pollution nicely illustrates why speed may be essential: rapid payment may be of particular importance, for example, for restaurants and hotels in coastal areas affected by offshore related pollution, but also for the fishing sector. Often those industries have financed their activities based on credit. Hence, when, for example, a fisherman or hotel owner loses income as a result of business interruption following an offshore related incident, this can have devastating consequences and potentially lead to bankruptcy since further income may be lacking, whereas loans still need to be paid back. ${ }^{3}$ Hence, the question arises of how payments, such as to hotel/restaurant owners and fishermen, can be guaranteed to prevent further damage resulting from their insolvency. Rapid payment importantly prevents a negative impact on social welfare because it prevents insolvencies. The policy argument in favour of a rapid claims mechanism is that a delay in payment could in fact lead to much higher damage, which rapid payment could precisely avoid.

From a proceduralist's point of view, the foregoing goes to the heart of the trade-off between complex tort litigation and less formalised forms of alternative dispute resolution (ADR). Law and Economics scholarship has developed insights regarding the feasibility of these different systems, taking Calabresi's work on tort/ accident laws as a starting point. ${ }^{4}$ Thereby, the two goals of tort law serve as a benchmark: deterrence and compensation. A (potential) tortfeasor needs to be induced to take optimal care by making him face an adequate remedy. An adequate remedy would be the one that ensures that he internalises the social costs of his behaviour, ie exposes him to the full risk of his actions. This prospect can deter a legal violation ex ante. The second goal of tort law is victim compensation. In this article, we will analyse to what extent disaster-based ADR systems of rapid claims settlement can fulfil these goals. Particular attention will be paid to unique benefits that fast compensation generates by preventing certain follow-on damage from occurring in the first place(1).

1 Often the example of the Exxon Valdez litigation in the USA is quoted. The incident happened in 1989 and litigation was concluded only after 2010, hence taking more than 20 years. See Edward Sherman, 'The BP Oil Spill Litigation and Evolving Supervision of Multidistrict Litigation Judges' (2011) 30 Miss C L Rev 237.

2 Under Belgian law, the civil claims of the victims under tort are postponed as long as a criminal procedure dealing with the technological accident has not been finalised. This is the case both if the victims pursue their civil claim in the criminal procedure or when they pursue a separate claim before the civil court.

3 See Kristel De Smedt, Michael Faure and others, Civil Liability and Financial Security for Offshore Oil and Gas Activities (2013) 324 <http://ec.europa.eu/dgs/energy/tenders/doc/2013/20131028_b3-978-1_ final_report.pdf $>$ accessed 24 August 2015.

4 See Guido Calabresi, The Costs of Accidents: A Legal and Economic Analysis (5th edn, Yale UP 1977). 
We will set out the relative strengths and weaknesses of (mass) tort litigation via civil courts, as opposed to alternative solutions such as $\operatorname{ADR}(2) .{ }^{5} \mathrm{Next}$, we will describe (3) and analyse (4) two recent American and European models of rapid claims management as alternatives to classical complex tort litigation: the American Gulf Coast Claims Facility (GCCF) that compensated victims of the Deepwater Horizon incident and the compensation mechanism for victims of technological accidents which was created in Belgium in the aftermath of a disaster involving an exploding gas pipeline. Finally, design suggestions for a workable format of a rapid claims mechanism will be provided, inspired by the assessment of the real life solutions (5). The last section concludes.

\section{COURTS VERSUS ADR: THEORY}

Whereas our understanding of civil procedure is rather straightforward referring to dispute resolution via a civil court, $\mathrm{ADR}$ may comprise a variety of mechanisms, that can be classified as ADR in its entirety or show some characteristics of it. ${ }^{6}$ For the purpose of this study, disaster-based ADR shall be any out-of-court procedure with considerably fewer formalised procedures, providing fast outcomes at low/no costs for the claimant.

The starting point for the analysis is Calabresi's seminal work which holds that the goal of accident law is to minimise the total social costs of accidents. He classifies the social costs of accidents as primary (the cost of accident avoidance and the expected damage), secondary (they materialise in the absence of optimal risk-spreading) and tertiary (the costs of administering any scheme designed to reduce the other two types of accident costs). ${ }^{7}$ Secondary costs respond to fairness concerns rather than to efficiency concerns.

For the upcoming comparison, we assume that ADR systems are less costly to administer. ${ }^{8}$ To the extent that a rapid claims mechanism can compensate at lower cost than the traditional court system, they entail a reduction of tertiary accident costs. As a peculiar benefit $\mathrm{ADR}$ solutions will always be able to provide more speedy payment and thus reduce primary accident costs by avoiding follow-on damage. To assess whether $\mathrm{ADR}$ is, therefore, superior to court litigation in the given situation, we need to check if the goals of tort law can likewise be achieved. In other words, we have to ensure that this strength is not outweighed by other costs such a system may lead to. A second set of questions concerns the matter whether ADR is also warranted for cases where time is not of essence.

5 In Belgium (Section 3.2), such an alternative consists of a compensation mechanism based on administrative law. To a large extent the trade-offs with litigation via the civil courts are the same as with ADR, as a result of which we discuss those mechanisms together.

6 The analysis will abstract from the many differences between European and American civil procedural rules_like availability of punitive damages basically only in the USA-and only refer to the crucial differences where relevant for the analysis.

7 Calabresi (n 4) 24.

8 For the case of consumer law there seems to be consensus: Gerhard Wagner, 'Private Law Enforcement Through ADR: Wonder Drug or Snake Oil' (2014) 51 CML Rev 165, 183 ('on average'). 


\subsection{Assessment Criteria}

When carefully assessing the potential of law enforcement mechanisms to work towards fulfilling the functions of tort law, two stages: the initiation phase of a claim and the execution of the claim handling need to be considered. In this respect we distinguish between elements that can affect the victim's incentives to file a claim or bring a lawsuit (1) and the incentive structure of the stakeholders in the enforcement mechanism (2). Afterwards, we will examine how those elements play out in the comparison between civil litigation and $\mathrm{ADR}$ (in Section 2.3).

\subsubsection{Initiation phase: victim's incentives}

Given the assumption of risk aversion there may be various problems distorting the incentives of victims in bringing meritorious lawsuits. The first problem that can arise is the so-called 'rational apathy' problem. The rational individual will not act if costs outbalance the benefits, for instance when the harm is very small and the investment to enforce the law is costly. ${ }^{9}$ If harm to the society is large and law enforcement desirable, for example in a case of small and widespread harm, no action may be taken because of a divergence between the individual and social incentive to sue. ${ }^{10}$ Even if harm is not minimal, economies of scale may be achievable by joining such type of claims. The matter may likewise be mitigated by fine-tuning the amount of compensation, eg by way of enabling punitive damages.

Another problem could equally arise, being that there are cases in which, instead of the suing party, the defendant turns out to be the victim-the victim of a 'frivolous lawsuit' that is not based on merits and socially not desirable. ${ }^{11}$ This becomes particularly worrisome if a wrong decision is taken, based on such a frivolous action. Such a wrong decision in economic terms would fall in the category of error costs. ${ }^{12}$ Error costs can generally be divided into two groups: Error I costs are those that occur when an individual who is guilty might mistakenly not be found liable ('mistaken acquittal'). ${ }^{13}$ Error II costs, on the other hand, occur if an innocent individual might mistakenly be found liable ('mistaken conviction'). Both cases dilute deterrence and thus reduce efficiency. They likewise conflict with compensatory goals.

\subsubsection{Claims handling: incentive structure of the stakeholders}

As far as the incentives of the stakeholders in the dispute settlement mechanism are concerned, a first problem that can occur is capture by, for instance, industry

9 See Roger Van den Bergh. 'Should Consumer Protection Law Be Publicly Enforced?' in Willem Van Boom and Marco Loos (eds) Collective Enforcement of Consumer Law (Europa Law Publishing 2007) 184.

10 See William Landes and Richard Posner, 'The Private Enforcement of Law' (1975) 4 JLS 1, 33.

11 See Andrea Renda and others, Making Antitrust Damages Actions More Effective in the EU: Welfare Impact and Potential Scenarios (2007) 562, Report for the European Commission Contract DG COMP/2006/ A3/012, prepared in Brussels, Rome and Rotterdam.

12 See Richard Posner, 'An Economic Approach to Legal Procedure and Judicial Administration' in Francesco Parisi (ed), The Economic Structure of the Law: The Collected Economic Essays of Richard A. Posner (Edward Elgar 2000) 290-349, 291.

13 See A Mitchell Polinsky and Steven Shavell, 'The Theory of Public Enforcement of Law' (2005) NBER Working Paper 11780, $36 \mathrm{ff}$. 
interests. ${ }^{14}$ The concept, which was originally developed to describe the capturing of public authorities can be expanded to the capturing of enforcement agencies like courts or the personnel of ADR bodies. ${ }^{15}$ The capture problem is likewise interlinked with the risk of error costs. As previously mentioned, whether error costs occur depends largely on the accuracy with which a system operates. ${ }^{16}$

A second potential distortion is related to the principal agent problem. Principal agent problems more specifically occur in a client/lawyer relationship. ${ }^{17}$ Generally, in these relationships the client (principal) cannot fully control the quality of the lawyer's (agent's) performance due to an information asymmetry, ${ }^{18}$ which can lead to moral hazard.

The above-mentioned elements can distort the goals of tort law. Only if the system is considered a real threat by the potential tortfeasor, afraid that he will face the social costs of his activities, will the deterrence function work. Only a well-working system ensures adequate victim compensation. We will now examine how the potential distortions may affect the choice between civil litigation and ADR and how far the additional benefit of $\mathrm{ADR}$ in terms of preventing follow-on damage is significant.

\subsection{Strengths and Weaknesses of Complex Civil Litigation Vis-À-Vis ADR}

The analysis of the two mechanisms will be tailored to the pollution example initially given where damage was caused to businesses in coastal areas that have financed their activities based on credit and are, therefore, particularly vulnerable.

\subsubsection{Initiation phase: victims' incentives}

To start with, in the case of the pollution example, the damage suffered by the victim (eg in the case of economic loss due to oil pollution) could be substantial. It can, therefore, be assumed that in principle the victim is prepared to invest in a lawsuit. However, as mentioned, there will be risk aversion with respect to the costs of the procedure, aggravated by its duration. Going back to the example of a local fisherman or restaurant owner facing bankruptcy it may indeed not be far-fetched that these individuals have no resources to invest in litigation at their availability-not even to make advance payments which they would be able to reclaim once the case is closed. The typical characteristics of $\mathrm{ADR}$, leading to no/low procedural fees and no lawyer

14 See Anthony Ogus, Regulation: Legal Form and Economic Theory (Clarendon Press 1994) 57. The concept of (regulatory) capture refers to public agencies that instead of acting in the public interest advance those of interest groups that, for instance, dominate the industry or sector it is in charge of.

15 For consumer law: Christopher Hodges, Iris Benöhr and Naomi Creutzfeldt-Banda, Consumer ADR in Europe - Civil Justice Systems (Hart Publishing 2012) 444.

16 Administrative and criminal law procedures are typically contrasted in this regard: Anthony Ogus, Michael Faure and Niels Philipsen, Best Practices for Consumer Policy: Report on the Effectiveness of Enforcement Regimes (2006) 47, Report prepared for the UK Department of Trade and Industry and OECD.

17 See Steven Shavell, 'The Fundamental Divergence between the Private and the Social Motive to Use the Legal System' (1997) 16 JLS 575, 599.

18 See Steven Shavell, 'Risk Sharing and Incentives in the Principal and Agent Relationship' (1979) 10 Bell J Econ 55; Hugh Collins, Regulating Contracts (OUP 1999) 236. 
fees, make it prima facie an attractive candidate for the victims, reducing the rational apathy problem. This is, of course, only true if the benefits-ie the compensation granted $^{19}$ and the extent to which a decision taken by an ADR body can be considered binding - are also to the victims' liking. The remedy would need to satisfy the deterrent effect on the tortfeasor.

Alternatively, in looking for solutions outside of the court in a scenario in which many parties are affected in similar ways, grouping such claims can reduce overall administrative costs and, hence, individuals' costs—-thereby improving the individuals' cost-benefit ratios.

Relaxed procedural rules such as in a low-cost $\mathrm{ADR}$ procedure may be a gateway for 'frivolous complaints'. Generally speaking, an enforcement mechanism would need to be able to filter out such types of claims. Prima facie the problem may have a more serious effect in the context of out-of-court solutions, leading potentially even to over-deterrence of the tortfeasor. In a similar way, the less accurate decision-making in out-of-court structures may increase the likelihood of error. ${ }^{20}$ This may potentially lead to both, over-and under-deterrence, the same as over-and undercompensation. Of course, there is scope for mitigating this problem in ADR design. In court, the problem is less serious from the outset primarily because of the more sophisticated procedural rules, including appeals procedures that apply. However, as soon as we talk about mass tort litigation as opposed to individual litigation, the susceptibility to frivolous complaints arises. ${ }^{21}$ Defendants may be pressured into nonbeneficial settlements.

\subsubsection{Claims handling: incentive structures of the stakeholders}

Two problems will be discussed in this section: the emergence of capture problems and principal-agent issues. Generally capture plays a greater role in nonjudicial structures, such as $\mathrm{ADR}$ or public agencies due to less safeguards being employed in selecting, remunerating and supervising personnel-thereby ensuring impartiality and independence. $^{22}$ One possibility to reduce the danger of capture is to ensure the mixed composition of the entities. This way the different interest groups are represented and biased decision-making becomes less likely. Optimal incentives must be provided in the salary and reward structure and the source of the ADR body's financing. Accountability and appeal options are other possible cures. This way it can be ensured that the ADR body carries out its tasks in line with how a society envisages it. The concern for capture is less with regard to civil judges. ${ }^{23}$ Judges are usually

Steven Shavell, 'The Optimal Structure of Law Enforcement' (1993) 36 JLE 255, 267. Compensation is an important motive for individuals to sue.

20 This reasoning is analogous to that stipulated for administrative versus criminal law procedures and their differences; for those findings, see: Ogus, Faure and Philipsen (n 16) 47.

21 Compare the situation of competitors in antitrust cases, Andrea Renda and others (n 11) 563. See Sonja Keske, Group Litigation in European Competition Law: A Law and Economics Perspective (Intersentia 2010) 104, 111.

22 See Thomas Main, 'ADR: The New Equity' (2005) 74 U Cin L Rev 329, 330.

23 See Richard Posner, ‘The Theories of Economic Regulation' (1974) 5 Bell J Econ 335, 351ff. For criminal law judges, see Roger Bowles, Michael Faure and Nuno Garoupa, 'The Scope of Criminal Law and Criminal Sanctions: An Economic View and Policy Implications’ (2008) 35 JLS 389, 392ff. 
nominated for life and their salary is fixed as a result of which they can be more independent and are less vulnerable to capture.

A logical advantage is given in the $\mathrm{ADR}$ context because if such a procedure does not require the involvement of a lawyer, the principal-agent problem does not arise. Mass litigation initiated by lawyers or other representatives is a particular challenge for the principal agent issue as the monitoring becomes even more complicated. Capture may likewise play with a group representative. A representative, such as a victims organisation may not necessarily always represent the interests of its clients but rather pursue its own goals.

One important consideration relates to the amount of captured players acting in the context of an enforcement response. Whereas in court it may be mainly the representative, in any $\mathrm{ADR}$ procedure it may not only be the representative but also the decision-maker within the ADR structure. Hence, results may be very uncertain. Therefore, in a procedure, one may want to reduce the amount of players that can be captured. There may be a benefit in involving an accurate decision-maker like a court. A general problem with mass cases is that they make frivolous lawsuits more likely because there is more at stake, and erroneous judgments/decisions would be extended over a whole group of individuals. ${ }^{24}$

\subsection{Interim Conclusion}

In the following, we will compare mass tort litigation in court with many individual complaints to an ADR mechanism. There may be a preference for ADR because such procedures are less formal and therefore faster and less costly for the individual and society. Low costs for individuals that have been hit by a catastrophe are indeed desirable. In the context of catastrophes, a fast procedure provides the additional benefit that the occurrence of follow-on damage can be avoided. In individual cases, $\mathrm{ADR}$ solutions cancel out potential principal agent problems between clients and lawyers as there is no need to involve a legal representative. However, the ADR-type of procedure may not be suitable for all types of cases. The advantages of an ADR procedure may come at a cost: out of court negotiations are characterised by less strict procedural laws. First, this may invite frivolous complaints. Secondly, this increases the danger of a mistaken decision, so-called error costs. Accuracy is capable of reducing these costs. Additionally, ADR will not lead to a further development of the law, which can be counted as a cost to society.

$\mathrm{ADR}$ procedures lead to less administrative costs and may, in this respect, be superior to mass court litigation. Do they, however, also score positively when it comes to ensuring that the goals of tort law are achieved?

At the stage of 'claims initiation' the challenge is the following: the positive effect of desirable low costs of $\mathrm{ADR}$ for the individual may not be offset by attracting nonmeritorious claims. In essence, it has to be ensured that the right cases are admitted to the procedure. If this can be guaranteed, reaching the goals of tort law may potentially be ensured by $\mathrm{ADR}$ procedures. If the goals are reached, then, it depends on 
the claims handling procedure. In essence, the question is whether the cases are decided accurately.

We have identified cases where follow-on damage is imminent if a solution is not reached quickly as a category of cases where $\mathrm{ADR}$ generates a benefit that the court system is not able to produce. Here, the cost-benefit calculation may speak in favour of $\mathrm{ADR}$ more easily than if cases where speed is not of essence are litigated. To take advantage of certain features of an $\mathrm{ADR}$ solution, such a nonjudicial procedure needs to be designed carefully and with caution. This may be warranted since after all, long court procedures also send the wrong signals to potential tortfeasors about the probability of being held liable. Looking back at the court system once more, in mass litigation we cannot eliminate the intermediary: a lawyer or any other kind of representative and negative incentive effects are possible during the procedure. Therefore, the spreading of error may be an issue in this context as well. In fine-tuning the system it is also important to consider if $\mathrm{ADR}$ and civil procedures can in any way be interlinked. If, for instance, an appeal in court was allowed regarding an ADR award, this may increase the accuracy of such a procedure. However, it may also lead to more administrative costs.

Thus summarising, for the assessment of two real-life examples that lie at the heart of mass court litigation and ADR, particular attention will be given to the following matters:

- The administrative costs of the system.

- If the goals of tort law can be reached with $\mathrm{ADR}$ procedures by looking at:

- The degree of accuracy of the procedures

- The interests of the players involved

- The interrelation between the two mechanisms.

- If the additional benefits of preventing follow-on damage are not outweighed by other costs of ADR and what this finding means for cases in which 'time' is not of essence.

\section{RAPID CLAIMS MECHANISMS: TWO EXAMPLES}

In the following section, we will discuss two recent attempts to respond to the need for fast victim compensation. The American Feinberg programme in the Deepwater Horizon case and the Belgian compensation fund for technological incidents will be discussed. These are only two among an array of other solutions with similar features. One can think of no-fault workers' compensation schemes, or other types of funds and insurance as alternatives to or enhancements of the tort system. Systems of disaster relief where no full compensation is provided to victims, but support for emergency measures, exist as well. ${ }^{25}$ It is our specific aim to discuss two examples of

25 For example, in Japan, a Disaster Relief Act provides 'for government emergency measures to protect victims of disaster and maintain social order by causing the central government to provide needed relief services on an emergency basis in cooperation with local public entities and the Red Cross, other entities, and the people of Japan', see MG Faure and J Liu, 'The Tsunami of March 2011 and the Subsequent Nuclear Incident at Fukushima: Who Compensates the Victims?' (2012) 37 Wm \& Mary Env L \& Pol Rev 129, 154. 
mechanisms that stay within the tort system. The findings may be relevant for many of the other systems as well.

\subsection{Claims Settlement in the Deepwater Horizon Case: The GCCF}

The US enacted the Oil Pollution Act (OPA) 1990 in response to the Exxon Valdez accident in $1989 .^{26}$ Section 2713 of OPA sets forth the procedures for claims handling after the occurrence of an incident. Following a spill, the President, acting through the Coast Guard, identifies the responsible party, which is required to advertise that it has been designated as the responsible party and to provide information about how claims can be pursued. ${ }^{27}$ As a first step, each claimant must submit his claims for removal costs or damages to the responsible party for payment. The designated responsible party has 90 days to respond to this claim. If the responsible party denies all liability for the claim or does not settle the claim by making payment within 90 days, the claimant has an option. He may either file a lawsuit against the responsible party, or make a claim against the Oil Spill Liability Trust Fund (OSLTF). Financing of the fund is ensured by a number of sources: a per-barrel excise tax collected from the oil industry on petroleum produced in, or imported to, the USA (largest share), transfers from previously existing pollution funds (finalised), interest on the fund principal from US Treasury investments, cost recoveries and fines and civil penalties under OPA.

Only under very limited circumstances may a claim be presented directly to the Fund. ${ }^{28}$ Whenever a claimant files a lawsuit, he temporarily waives his right to make a claim to the OSLTF. If a claim is not or not fully compensated after the court procedure was finalised, then the claimant may subsequently make a claim against the OSLTF. The OSLTF hence works, on the one hand, as an alternative to filing a lawsuit and on the other hand as a supplementary scheme. The presentment requirement under OPA is a mandatory condition before filing lawsuits against a responsible party-otherwise his claim will be dismissed. ${ }^{29}$ The clear aim of the OPA is to encourage settlement and avoid litigation. ${ }^{30}$

The Deepwater Horizon incident happened on 20 April 2010. In line with the GCCF a private claims facility under the OPA was provided that streamlined the presentment of claims ${ }^{31}$ The GCCF as structured under the OPA went far beyond what the OPA statute had envisaged. ${ }^{32}$ It, in fact, amounts to ADR. It took over the administration of the claims on 23 August 2010. Whereas the court option is normally only available after the 90 days period has elapsed, in the case of Deepwater

For a summary of the US OPA regime, see Colin De La Rue and Charles Anderson, Shipping and the Environment: Law and Practice (LLP 2009) and Robert Force, Martin Davies and Joshua Force, 'Deepwater Horizon: Removal Costs, Civil Damages, Crimes, Civil Penalties, and State Remedies in Oil Spill Cases' (2011) 85 Tulane L Rev 889.

27 See 33 USC, s 2714.

28 For a detailed discussion on the claims procedure, see Force, Davies and Force (n 26) 949-56.

29 ibid 950.

30 Samuel Issacharoff and D Theodore Rave, 'The BP Oil Spill Settlement and the Paradox of Public Litigation’ (2014) 74 Louisiana L Rev 397, 3. 
Horizon, claimants have the explicit option to file with the GCCF or in court. ${ }^{33}$ The GCCF-route was entirely voluntary. The GCCF allowed for three types of payments: quick payment, ${ }^{34}$ an interim payment ${ }^{35}$ and final payment. ${ }^{36}$ Once the GCCF-route was opted for, in some cases, payment by the GCCF excluded compensation from the court (in the case of the so-called quick and final payments); in other cases (with interim payments) this was not the case. ${ }^{37}$

The GCCF was set up quickly, but not immediately. Before 23 August 2010, BP dealt with claims via a claims process it had established through multiple claims centres. In fact this was the case as of 3 May 2010. ${ }^{38}$ According to BP, the company awarded US\$399 million in claims from 3 May till 23 August 2010 in transition to the GCCF. ${ }^{39}$ In essence within weeks after the Deepwater Horizon incident, BP had already begun to pay compensation for claims. On 16 June 2010, BP established a fund of US $\$ 20$ billion with an open-ended commitment should the amount turn out to be insufficient. ${ }^{40}$ Political pressure had undoubtedly been exerted on BP by President Obama to create such a fund. ${ }^{41}$

The GCCF claims facility was administered by Kenneth Feinberg and two independent trustees were appointed. ${ }^{42}$ Hence, someone else than the defendant (BP) held the funds. As said, it began to accept claims as of 23 August 2010. On that day, the GCCF issued its Protocol for Emergency Advance Payments, which established procedures for emergency advance payments by individuals and businesses. ${ }^{43}$ These mainly included compensation for the loss of earnings or profits, removal and cleanup costs, real or personal property damage, loss of subsistence use of natural

33 Thomas Schoenbaum, 'Liability for Damages in Oil Spill Accidents: Evaluating the USA and International Law Regimes in the Light of Deepwater Horizon' (2012) 24 JEL 395, 408. See also attempts of lawyers to seek the court's intervention in the GCCF, Colin MacDonell, 'The Gulf Coast Claims Facility and the Deepwater Horizon Litigation: Judicial Regulation of Private Compensation Schemes' (2012) 64 Stanford L Rev 765.

34 This implied filling out a form without any further documentation of damage and receiving a check within two weeks of \$5,000 for individuals and \$25,000 for businesses: Kenneth Feinberg, Who Gets What? Fair Compensation after Tragedy and Financial Upheaval (Public Affairs 2012) 168, and a corresponding obligation not to sue BP.

35 Based on past damage while remaining their right to sue and to return to the GCCF, ibid 169.

36 This would cover past, present and future damage on the condition of a full release promising not to sue and no right to return to the GCCF, ibid 171.

37 ibid 167-72; Myriam Gilles, 'Public-Private Approaches to Mass Tort Victim Compensation: Some Thoughts on the Gulf Coast Claims Facility' (2012) 61 DePaul L Rev 427, 419.

38 <http://fpc.state.gov/documents/organization/159014.pdf > accessed 24 August 2015.

39 Jonathan Ramseur, 'Liability and Compensation Issues Raised by the 2010 Gulf Oil Spill', Congressional Research Service Report for Congress (R41679, 11 March 2011) 15. See also BP Press Release, 17 August 2010, http://www.bp.com/en/global/corporate/press/press-releases/bp-readies-for-transfer-to-gulf-coastclaims-facility-as-claim-payouts-top-368-million.html.

40 The White House, FACT SHEET: Claims and Escrow (Press Release, 16 June 2010) < http://www.whitehouse.gov/the-press-office/fact-sheet-claims-and-escrow $>$ accessed 24 August 2015.

41 Feinberg (n 34) 130.

42 An unprecedented trust, Syverud answers call to oversee BP's \$20 billion fund for oil spill victims, 17 October 2010 http://www.bizjournals.com/stlouis/stories/2010/10/18/focus3.html?page=all. Interview with Kent Syverud in Saint-Louis on 5 March 2013. Kenneth Feinberg is also known for having administered the September 11th Victim Compensation fund and has overseen a large number of other funds.

43 Gulf Coast Claims Facility Protocol for Emergency Advance Payments, Gulf Coast Claims Facility, s II (F), 23 August 2010. 
resources, and physical injury or death caused by the spill. On 22 November 2010, the GCCF issued a Protocol for Interim and Final Claims, which the GCCF subsequently revised on 8 February 2011. ${ }^{44}$ The GCCF received claims for both interim payments designed to compensate claimants for past losses and final payments designed to compensate claimants for past and future losses. ${ }^{45}$ According to a study commissioned by the US Department of Justice, within one and a half years, the GCCF processed over 1 million claims and paid a total of more than US\$6.2 billion to over 220,000 individual and business claimants. Approximately, 99.8\% of the number of claims and $96.8 \%$ of the amounts paid related to lost earnings or profits. ${ }^{46}$

In parallel to the establishment of the GCCF, litigation in court took place. Importantly, a large number of pending lawsuits against BP and the other defendants concerning the Deepwater Horizon Incident were consolidated before one court in August 2010. ${ }^{47}$ This consolidated multidistrict litigation (MDL) ended in a settlement between the Plaintiffs' Steering Committee and BP regarding economic and property damages. ${ }^{48}$ The US District Court in New Orleans entered an Order on 21 December 2012, granting Final Approval to the settlement. With the approval by the court US\$7.8 billion was set aside for economic loss payments for class members who were affected by the BP Deepwater Horizon oil spill-the deal was furthermore uncapped. In essence, in June 2012 the GCCF office was closed and the new BP settlement replaced the GCCF claims programme in the OPA structure. Patrick Juneau, a Lafayette, Louisiana attorney, oversees the settlement agreement. Claimants had until April 2014 to file a claim. Generally those victims who received a payment from the GCCF and executed a GCCF Release and Covenant not to sue were excluded from the settlement. ${ }^{49}$ Some literature formulates this move as a hostile takeover. ${ }^{50}$ Following an appeal, the Fifth Circuit of the US Court of Appeals affirmed the District Court's Order in a decision of 10 January $2014 .^{51} \mathrm{BP}$ is still pursuing further legal action. ${ }^{52}$ This was not the only settlement agreement that was concluded. ${ }^{53}$ Others involve medical claims.

The procedure of these two different regimes-the GCCF and the settlement procedure-has triggered scholarly reaction, arguing that the amounts paid by

For an analysis of the function of GCCF, see Force, Davies and Force (n 26) 936-37.

BDO Consulting (commissioned by the US Department of Justice), Independent Evaluation of the Gulf Coast Claims Facility: Report of Findings and Observations, 5 June $2012<$ http://www.justice.gov/opa/ documents/gccf-rpt-find-obs.pdf $>$ accessed 24 August 2015.

46 ibid 62.

47 In re Oil Spill by the Oil Rig 'Deepwater Horizon' in the Gulf of Mexico on April 20, 2010 MDL No 2179, 731 F Supp 2d 1352 (JPML 2010)

48 <http://www.deepwaterhorizoneconomicsettlement.com/docs/statistics.pdf > accessed 24 August 2015.

49 <https://cert.gardencitygroup.com/dwh/fs/faq?.delloginType=faqs\#Q2 > accessed 24 August 2015.

50 See Linda Mullenix, 'Designing Compensatory Funds: In Search of First Principles' (2015) 3 SJCL 1, 31.

51 US Court of Appeals Fifth Circuit, Case IN RE: Deepwater Horizon - Appeals of the Economic and Property Damage Class Action Settlement No 13-30095 <http://caselaw.findlaw.com/us-5th-circuit/ 1654784.html> accessed 5 October 2015.

52 Ed Crooks, 'Appeals Court Upholds BP Deepwater Horizon Settlement' Financial Times (11 January 2014) <http://www.ft.com/cms/s/0/16525a28-7ab0-11e3-80ff-00144feabdc0.html\#axzz2r82VauAY> accessed 5 October 2015.

53 <http://www.bp.com/en/global/corporate/gulf-of-mexico-restoration/claims-information.html > accessed 24 July 2015. 
Feinberg were lower than those paid later on. ${ }^{54}$ The settlement is of an opt-out nature, which means that every class member is bound by it unless he takes the active decision to leave the group. Indeed, some claimants did opt out of the settlement. The deadline to opt out of the Settlement was 1 November 2012. ${ }^{55}$ The GCCF has, consequently, only dealt with a share of the claims. A considerable amount of litigation has happened nevertheless and satellite litigation is still unresolved. ${ }^{56}$ It can be extracted from the latest claims administrator's status report (No 22, of 1 July 2014) with respect to the class settlement that over US\$3.93 billion was paid out on 62,328 claims following the settlement agreement. ${ }^{57}$

\subsection{Compensation for Victims of Technological Accidents in Belgium}

A new Belgian Act was promulgated on 13 November 2011 concerning the compensation for victims of technological accidents; this came into force on 1 November $2012 .^{58}$ Its emergence was related to the disaster of an exploding gas pipeline operated by Fluxis, a Belgian company that happened on 30 July 2004 in Ghislenghien. As a result of this accident, 24 people died and more than 150 were injured. Since in Belgium civil procedure is linked to criminal procedure ${ }^{59}$ most of the victims were only compensated many years after the incident. This explains the need for a new act with the specific aim of accelerating victim compensation. ${ }^{60}$

The Act applies to so-called 'technological disasters of great extent', which are defined as a technological incident involving bodily injury to at least five persons (through death or hospitalisation). The Act will apply when a specific committee (referred to as a committee of wise men) ${ }^{61}$ declares the incident to be an exceptional disaster and victims shall claim compensation within six months from the publication

54 Issacharoff and Rave (n 30).

55 FAQs: <https://cert.gardencitygroup.com/dwh/fs/faq?.delloginType $=$ faqs\#Q3 $>$.

56 Mullenix (n 50) 3.

57 <http://www.deepwaterhorizoneconomicsettlement.com/docs/CA_Report_No.22.pdf > accessed 24 August 2015.

58 Wet betreffende de vergoeding van de lichamelijke en morele schade ingevolge een technologisch ongeval (Law concerning the bodily injury and immaterial damage following a technological accident), 13 November 2011, Belgian Official Journal Moniteur Belge, 24 February 2012. For commentaries, see inter alia C Coune, 'Wet van 13 november 2011 betreffende de vergoeding van de lichamelijke en morele schade ingevolge een technologisch ongeval' (2012) 5 Tijdschrift voor Belgisch Handelsrecht, 5; Elisabeth Verjans, 'Nieuwe wettelijke regeling voor de vergoeding van slachtoffers van grote technologische rampen' (2012-2013) 27 Rechtskundig Weekblad 1076.

59 This means that the victims cannot be compensated via civil liability as long as the criminal procedure is ongoing.

60 For an overview and critical discussion of (consumer) ADR in Belgium, see Stefaan Voet, 'Belgium' in Christopher Hodges, Iris Benöhr and Naomi Creutzfeldt-Banda (eds), Consumer ADR in Europe. Civil Justice Systems (Hart 2012) 25; Stefaan Voet, 'Public Enforcement and A(O)DR as Mechanisms for Resolving Mass Problems: A Belgian Perspective in Christopher Hodges and Astrid Stadler (eds), Resolving Mass Disputes: ADR and Settlement of Mass Claims (Edward Elgar 2013).

61 This committee is mentioned in Art 4 of the Act and is nominated by the King. Art 4(1) holds that there should be representatives inter alia of the Ministry of Justice, the Ministry with competence for insurance, the Ministry of Finance, the Health Ministry as well as representatives of insurers and of a consumer association. 
of the decision of the committee. ${ }^{62}$ Compensation matters are then taken care of by the Belgian motor insurance guarantee fund. A Special Unit in charge of victims support is also constituted by the public prosecutor that establishes a list of victims and communicates this list to the Fund. ${ }^{63}$ Victims can ask for compensation by addressing either the Fund or the Special Unit by registered letter. The fund in principle only compensates bodily injury and its intervention is subsidiary to social security and insurance mechanisms. Victims are free to choose to claim under the Act or under the general Belgian Civil Liability Law, ie Belgian tort law. The Act does not specify the conditions under which the fund will compensate. Article 10 of the Act only specifies that the fund will compensate the victim or their descendants according to the rules of common law, taking into account the exceptional character of the damage.

Within three months after the fund has received the list of the victims, the administration of the fund will formulate an informed advice explaining whether the damage is of such a nature that it should be compensated on the basis of the statute. If the advice regarding compensation is affirmative and if the damage can be quantified, it will provide an offer of compensation. ${ }^{64}$ This offer is final. According to Article 14, acceptance of the final offer from the fund to the victim will be considered as a final settlement of the case. If the victim does not agree with the decision of the fund, according to Article 10 he can sue the fund before the civil court.

The financing is based on pre-payment by insurance companies. Article 16 holds that when the decision of the committee of wise men to declare the incident a technological disaster has been published, the fund will make an estimate of the damage and subsequently ask private insurers to pay to the fund on the basis of their market share. Insurers active in the area of civil liability insurance (with the exception of insurances covering liability in the field of motor vehicles) are forced to contribute to the fund on the basis of Article 16, para 2. The total maximum amount insurers will have to contribute is 50 million Euros per year. ${ }^{65}$

The fund is, moreover, subrogated in the rights of the victim against the liable tortfeasor and his insurer. ${ }^{66}$ Article 17 sets out that the fund recovers the damages paid, including the interest as well as the fees and costs for managing the fund, from the liable tortfeasor and its insurer. When no liable tortfeasor can be identified or when it is not possible to recover the amounts from the liable tortfeasor (because of his insolvency) the fund requests repayment from the National Disaster Fund. The amounts that can hence be recollected by the fund from either the tortfeasor (or his liability insurer) or from the National Disaster Fund will then, according to the market share, be paid back to the insurance companies that contributed in the first place. Article 20, however, stipulates that if after a procedure it appears that there is no liable tortfeasor, the entire costs of the compensation will be paid by the National Disaster Fund. If, on the other hand, there is a liable tortfeasor, but it is impossible

63 This special unit is mentioned in Art 6 of the Act and is meant to provide support and assistance to the victims. This special unit is hence different than from the Fund.

64 See Art 13 of the Belgian Act.

65 Art 16, para 5 of the Act of 13 November 2011.

66 Art 9, para 4 of the Act of 13 November 2011. 
to obtain compensation from him (because of insolvency) the National Disaster Fund takes care of $50 \%$ of the costs that could not be recovered. The remaining $50 \%$ will in that case presumably remain with the insurers who contributed. Regarding the Ghislenghien incident in which the fund intervened, all 140 files have been closed, leading to a total compensation of EUR 6,599,919. ${ }^{67}$

\section{ASSESSING THE EXISTING REGIMES}

After setting out how these two mechanisms work they will be assessed in the light of our theoretical findings. We will, more particularly, verify to what extent the mechanisms discussed are able to provide speedy compensation to victims while at the same time still exposing potential tortfeasors to the social costs of their activities.

\subsection{Critical Review of the GCCF}

The GCCF has been disapproved of in various legal publications, particularly questioning if it led to better outcomes than in a comparable tort case. ${ }^{68}$ On the other hand, positive mention has been made of the GCCF in this literature when it comes to, among others, speed, low costs and cost certainty. ${ }^{69}$ The GCCF is said to have the ability to 'forestall the potentially devastating effects on families and local areas directly impacted'. ${ }^{70}$ Compared with the lengthy and costly litigation, such private funding may have the advantage of 'distributing funds to affected claimants more quickly and at less cost to the claimants'. ${ }^{71}$ Our critical analysis will add the Law and Economics point of view in line with the theoretical arguments set out above.

In the approximately one and a half years of its existence the GCCF was able to compensate a certain number of victims and, moreover, to do this relatively rapidly and at lower cost than the tort system. Originally, more than 1 million claims were handed in. ${ }^{72}$ Eventually, the GCCF paid out more than US\$6 billion ${ }^{73}$ to more than 500,000 claimants. $^{74}$ By reducing administrative costs, more money was available for victim compensation. ${ }^{75}$ During the period of 16 months, 3,000 employees were

67 See Annual Report 2012, Fonds Commun de Garantie Automobile (=Belgian motor insurance guarantee fund) 12, < http://www.fcgb-bgwf.be/documents/Rap-Ver/RAPPORT_2012_FCGA.pdf > accessed 25 August 2015.

68 See Linda Mullenix, 'Prometheus Unbound: The Gulf Coast Claims Facility as a Means for Resolving Mass Tort Claims-A Fund Too Far' (2011) 71 Louisiana L Rev 819, Mullenix (n 50) 2: See eg Arthur Ewenczyk 'For a Fistful of Dollars: Quick Compensation and Procedural Rights in the Aftermath of the 2010 Deepwater Horizon Oil Spill' (2013) 44 J Mar L \& Com 267; MacDonell (n 33) 796; Tracy Thomas 'Introduction, Symposium: Remedies for Big Disasters: The BP Gulf Oil Spill and the Quest for Complete Justice' (2012) 45 Akron L Rev 567, 570 reports how the outcome of the Symposium 'Remedies for Big Disasters: the BP Gulf Oil Spill and the Quest for Complete Justice' has overall been negative regarding the evaluation of the GCCF.

69 See by way of example Deborah Greenspan and Matthew Neuburger, 'Blowout: Legal Legacy of the Deep Water Horizon Catastrophe: 'Settle or Sue? The Use and Structure of Alternative Compensation Programs in the Mass Claims Context' (2012) 17 Roger Williams U L Rev 97.

70 See Greenspan and. Neuburger (n 69) 99.

71 ibid.

72 Feinberg (n 34) 167.

73 Ibid 175 .

74 ibid 174.

75 Interview with Kent Syverud in Saint-Louis on 5 March 2013. The interview took place within the framework of a report drafted for the European Commission on civil liability and financial security for offshore 
working for the GCCF in 35 offices at an approximate cost of US\$40 million per month. ${ }^{76}$ Generally in the USA in mass damage class actions one-third of the available compensation goes to plaintiffs' lawyers. In comparison the expenses of running the GCCF are modest. ${ }^{77}$ The GCCF scheme has the potential to solve disputes faster than US mass tort litigation and is capable of producing the additional benefit of fast compensation, whereby preventing follow-on damage. What about its overall performance with a view to the goals of tort law?

\subsubsection{Initiation Phase: Victims' Incentives}

The prospect of receiving fast compensation serves to trigger individual claims because a victim knows that their efforts will not be in vain and compensation will come early enough to prevent an imminent bankruptcy, for example. The GCCF mechanism also fares positively with regards to the costs incurred for individuals, thus reducing rational apathy. Victims simply have to fill in the claims form. Online and in claims centres victims were provided with help on how to fill in these forms. Substantial amounts could be paid out rapidly (most victims were paid in less than three years after the incident). ${ }^{78}$ Another positive characteristic of the procedure from the victims' point of view is the fact that it was left to their choice if they wanted to follow this fast procedure or sue BP individually. Emergency advance payments could, furthermore, be obtained which would be deducted from the final payments.

The mere fact that initially it was signalled to the victims that US\$20 billion were available undoubtedly had an attractive effect on the amount and number of (perhaps some fraudulent) claims. ${ }^{79}$ This is also shown by the anecdotal evidence that originally more than 1 million claims were handed in ${ }^{80}$ whereas finally 'only' around 500,000 claimants received compensation. ${ }^{81}$ Arguably, the system was able to filter out some of the frivolous complaints.

Complex systems, whereby for example a rapid claim mechanism exists in addition to the tort system may raise an individuals information costs. That, however, did not seem to be a major issue in the case of the GCCF. Not only did the GCCF in the end only last for a limited time; before and afterwards claims were administered in a different fashion. Furthermore, if claimants did not use the GCCF they could present an individual claim to BP and then either sue them or file a claim to the OSLTF. This fund shifts a certain amount of the compensation payment burden away from the tortfeasor. ${ }^{82}$ It is capped at US\$1 billion per incident. ${ }^{83}$ We can only

oil and gas activities <http://ec.europa.eu/dgs/energy/tenders/doc/2013/20131028_b3-978-1_final_ report.pdf $>$, the information provided in the interview also gave useful insights for the topic of this study. Interview with Kenneth Feinberg, special administrator of the GCCF in Haifa on 16 June 2013. The interview equally took place within the framework of the study mentioned in the previous footnote.

77 Ibid

78 Interview with Kenneth Feinberg, special administrator of the GCCF in Haifa on 16 June 2013.

79 In the words of the special administrator of the fund, Kenneth Feinberg, 'entire communities had their eyes on the price: $\$ 20$ billion ready to be distributed immediately'; Feinberg (n 34) 146.

80 ibid 167.

81 ibid 174.

82 See the discussion on the financing of the OSLTF in Section 3.1.

8326 USC $\$ 9509(\mathrm{c})(2)(\mathrm{A})(\mathrm{i})(2012)$. 
speculate about the information that individuals have regarding which route- the court or the fund-is more beneficial to them. The numbers reveal that the fund has been exhausted regarding the Deepwater Horizon incident. On 9 March 2012, the OSLTF status report revealed the following: ${ }^{84}$ Deepwater Horizon OSLTF Costs $=\$ 619$ million and Deepwater Horizon Pending Claims $=\$ 410$ million (for 1,659 claims received). Hence the total expenditure with US\$1.019 billion was to exceed the US\$1 billion expenditure cap and the fund was exhausted.

It is being argued that after the GCCF process, in which individuals had to actively file a claim, was closed, a paradigm shift happened with the settlement agreement as it has been constructed as an opt-out system. The additional finality it provided to BP is judged positively. ${ }^{85}$ Therefore, some authors favour a settlement solution through the courts, because it also led to higher awards for victims. It is interesting to notice that many of the critics of the GCCF were involved, either as attorneys or counsels for (some of the) claimants, which may undoubtedly have created some bias. ${ }^{86}$ Importantly, also from the settlement a certain proportion of individuals again opted-out. The value of the GCCF can only really be evaluated once all the settlements have been finalised, or rather can actually never really be evaluated because we cannot artificially construct a world without the GCCF. It is apparent though that the GCCF solution led to fast payments (also emergency payments) for victims. The individual payments made by the new BP settlement structure in absolute numbers look higher; however they came at a much later stage. Consequently, when discounting the value of the late payment to the present value, the difference may be minor or even shed a negative light on the amounts awarded in litigation. It is rather challenging to assess the amount leading to the desirable effects in terms of deterrence and compensation.

For both procedures it is true that a substantial share of the administrative costs was taken over by the defendant or the state and victims were relieved from bearing these costs. Setting up a general settlement procedure led to a certain amount of economies of scales.

\subsubsection{Claims handling: incentives of the enforcers involved}

Who are the administrators of the assets? In the GCCF there were, as indicated, two different parties: on the one hand, two independent trustees managed the fund, in the sense that they were responsible for making sure that the money allocated by BP was actually available for compensation. The decisions on the compensation claims of the victims were made by the special administrator Kenneth Feinberg and his team. $^{87}$ This is clearly a strength in the design. Moreover, the manager of the GCCF used ADR techniques inter alia to present a draft of the protocol for advanced payments to potential victims at many meetings that took place in various locations in

<http://donovanlawgroup.wordpress.com/2012/10/15/bp-oil-spill-victims-opt-out-of-the-deepwaterhorizon-class-action-settlements/> accessed 24 August 2015.

85 Issacharoff and Rave (n 30).

86 Schoenbaum (n 33) 395, represented several parties as attorney in the Deepwater Horizon litigation and Samuel Issacharoff (ibid) served as counsel to the plaintiffs steering committee. 
the US where victims were located. ${ }^{88}$ Hence, victims were involved in drafting the protocol which clearly stipulated the conditions under which payment would take place and, victims could have a voice in the formulation of this protocol, thus adding to the legitimacy of the procedure. Moreover, the protocol aimed to ensure that the administrators of the GCCF would make payments according to the clearly specified criteria. This method apparently allowed the administrator of the fund to verify the validity of the claims rapidly, equally allowing them to turn down many unjustified claims. This is, hence, a positive aspect regarding the required degree of accuracy in harmonising the procedure and making it predictable. It is a welcome fact that the procedure was easy enough to put victims in a position not to involve a lawyer in the procedure. Therefore, principal-agent situations of that kind could be avoided. It should be added that Feinberg's independence was occasionally questioned. ${ }^{89}$ On the one hand, Feinberg consulted with BP concerning both the substantive and procedural standards for the payment of claims-amounts were gradually increased while the system was already running. While he did not get a salary, his law firm would be paid US\$950,000 a month. There has also been criticism of the fact that it was made insufficiently clear that the GCCF was a structure which was independent from $\mathrm{BP}$, as a result of which the structure created suspicion among some claimants. $^{90}$

On a negative note, the costs of a consultancy firm (BDO) to verify the payments made to the victims were extremely high (US\$17 million). ${ }^{91}$ Third parties had insisted on an independent audit of the work of the GCCF. ${ }^{92}$ One still has to take into account that those payments to consulting firms are only a fraction of what would otherwise have been paid to law firms if the whole case had been tried in a court. It follows from the foregoing that it would be wrong to say that the incentives were more distorted in the ADR solution than before court. If a mass settlement in court is reached, such a settlement comes at an earlier stage than a verdict would be. Large amounts of Law and Economics literature, however, mention class lawyers' interests in negotiating early settlement to the detriment of their clients. ${ }^{93}$

88 ibid.

89 Edward Sherman, 'The BP Oil Spill Litigation and Evolving Supervision of Multidistrict Litigation Judges' (2011) 30 Miss C L Rev 237, 245 referring to Harry Webber, 'BP Increases Pay for Claims Czar Ken Feinberg's Law Firm to \$1.25 Million Per Month', Huffington Post Green (25 March 2011) <http:// www.huffingtonpost.com/2Oll/03/25/bp-ken-feinberg-claims-salary-pay.n_840871.html> accessed 24 August 2015.

90 So David Partlett and Russell Weaver, 'BP Oil Spilled: Compensation, Agency Costs and Restitution', (2011) 68 Washington \& Lee L Rev 1341.

91 ibid.

92 Feinberg reports that also the US Coast Guard had made a review of the compensation determination by the GCCF on the requests of 1612 claimants, both individuals and businesses 'and in every single instance, the Coast Guard ultimately agreed with the GCCF's determinations'; Feinberg (n 34) 178.

93 See Michael Faure, Fooke Fernhout and Niels Philipsen," 'No Cure, No Pay and Contingency Fees' in Mark Tuil. and Louis Visscher (eds), New Trends in Financing Civil Litigation in Europe - A Legal, Empirical and Economic Analysis (Edward Elgar 2010) 37; Paul Fenn and Neil Rickman, 'The Empirical Analysis of Litigation Funding' in Mark Tuil and Louis Visscher (eds), New Trends in Financing Civil Litigation in Europe - A Legal, Empirical and Economic Analysis (Edward Elgar 2010) 145. 


\subsubsection{Conclusion}

Our conclusion on the GCCF is on the whole positive. The creation of the GCCF functioned as a confidence builder. There was more particularly a fear among the victims that BP would not be able to fully compensate the damage. The creation of a fund with substantial assets created trust that BP (via the GCCF) would be able to meet its obligations. ${ }^{94}$ Likewise victims' involvement in setting up the protocols had this effect. Clearly administrative costs were lower compared to the alternative.

The GCCF can be regarded as a meaningful step in terms of identifying the desirable degree of procedural accuracy and taking care of the stakeholders' incentives, while still ensuring speedy compensation. ${ }^{95}$ Specifically the fact that victims were left with a choice on how to proceed, can be evaluated positively-even if it made them face information costs. ${ }^{96}$ When it comes to taking account of weaknesses in ADR procedures, such as scope for collusion and neglecting due process requirements, the design took due account of a significant number of those weaknesses-even if not perfectly: involving victims in the procedure, providing them with a choice of whether to choose ordinary tort law or the GCCF, and appointing independent trustees. Despite different amounts than those granted by the settlement, the deterrence function may still have been served. The compensation goal was very clearly achieved for the share of cases for which time was of essence.

One cannot view the GCCF in isolation though. A certain share of cases still went into civil litigation. Hence, overall administrative costs incurred were higher than only those attributable to the GCCF. It can only be speculated to what extent this is due to proactive lawyers. ${ }^{97}$ Typically settlements are not known for a high amount of transparency ${ }^{98}$ and leading to the best outcome for the claimants when measured against the functions of a tort law system. Up until reaching the settlement, substantial litigation and lawyer fees went into this process. Again it can only be speculated what the impact of the existence of the GCCF on the settlement outcome may have been. Clearly, for one and a half years, the GCCF was the only fast track system in place and it did resolve many cases. The conclusion might well be that the GCCF scores rather high in terms of adequacy of amounts being paid and that the shift of a large number of claims to systems outside the GCCF may have been inspired by motives other than ensuring accurate compensation and deterrence.

94 Interview with Kent Syverud in Saint Louis on 5 March 2013.

95 There are also more critical views on the GCCF. It is, for instance, being argued that the gains achieved by the fund solution have not been distributed to the polluters and the victims alike. The victims arguably would have been better off in court litigation, see Issacharoff and Rave (n 30).

96 We more particularly refer to the costs of choosing between the GCCF and the tort system via courts.

97 It may be clear that the plaintiff bar and the American Bar Association were strongly opposed to the GCCF. In the words of special administrator Feinberg 'So the GCCF was the enemy, a conspicious alternative to the time-honoured American way of resolving disputes in the court room': Feinberg (n 34) 157. This should not come as a surprise since the lower costs of the GCCF obviously were partially due to the fact that no plaintiff lawyers were involved in the claim settlement, which obviously meant a loss of business to them.

98 See Thomas ( $\mathrm{n}$ 68) 573. In that respect, the ADR solution provided by the GCCF was far more transparent (since it published clear criteria for compensating different categories of victims) than the settlement after the class action. 


\subsection{A Critical Review of Belgian Legislation}

Belgium has a statutory basis for a rapid claims settlement scheme. Presumably such a mechanism leads to lower administrative costs than court procedures. Then again at various stages throughout the procedure courts may still need to be involved. For example, if a victim does not agree with the final offer made by the fund's administration or if insurers want to claim their money back from the tortfeasor. Therefore, overall costs may still rise. How does the mechanism score with a view to ensuring the goals of tort law?

\subsubsection{Initiation phase: victims' incentives}

Again it seems feasible to assume that rational victims make a cost-benefit analysis of whether it is worthwhile to invest in obtaining compensation take this route, given that the costs involved in initiating such a procedure seem to be low. In fact there are no costs whatsoever involved for the victim. ${ }^{99}$ Again speedy compensation is the goal and it is also achieved when compared to civil procedures that would be pending until the criminal aspects of a case were dealt with. This has the potential to prevent large follow-on damage. An important factor for the success of the scheme is the availability of funds which is guaranteed by relying upon wealthy contributorsthe insurance sector. What could have a negative impact on an individual's action is the fact that it is, for example, far from clear what is the meaning of 'the victim will be compensated on the basis of common law. ${ }^{100}$ Does that mean that all heads of damage that the victim claims will automatically be compensated or will the fund, for example, still take into account the contributory negligence of the victim? This may have doubtful effects for both perspectives: the deterrence, as well as the compensation function. At the same time this lack of clarity may induce some frivolous complaints. Too little is known about the administration of the fund to establish whether it will successfully filter out all frivolous complaints. Victims are free to choose to claim under the Act or under Belgian Civil Liability Law. Again, the fact that victims can choose is undoubtedly positive. However, there may be large uncertainty with respect to the likely results when choosing either the fund or Belgian civil liability law. That uncertainty may hence create high information costs for the victims.

\subsubsection{Claims handling: incentives of the enforcers involved}

As mentioned above, generally speaking any out-of-court settlement solution is more prone to making errors or of decisions being captured than a court solution. In the Belgian administrative procedure, the players that this may affect are the Committee of wise men, the administrator of the fund and the Special Unit in charge of victims support as constituted by the public prosecutor. The most important decision-maker with a view to determining compensation claims is the administrator of the fund.

99 The types of cases that fall under the provision are arguably less likely to cause rational apathy than those under the GCCF scheme. The specific challenge that the outcome of the criminal procedure first has to be awaited has been referred to.

100 As Art10 of the Act of 13 November 2011 stipulates: 'Conf ormément aux règles de droit commun, en tenant compte du caractère exceptionnel du dommage' (in conformity with the rules of civil law and taking into account the exceptional character of the damage). 
The Belgian fund involves various insurers. Insurers active in the area of civil liability insurance (with the exception of insurances covering liability in the field of motor vehicles) have to pre-finance the fund, but can recover costs from the tortfeasor, its insurer, or the National Disaster Fund. There are thus various backups of insurers and funds in this system. Regarding the insurers' incentives a point of criticism is that it is unclear why all insurers active in Belgium, including those unrelated to the incident, would have to pre-finance the compensation to the victims. From a distributional point of view this seems rather odd. The more logical solution would seem to be to request pre-payment from the identified tortfeasor or his liability insurer. Next, in terms of providing correct incentives on top of this debatable solution, it is even less understandable why these insurers should risk to lose $50 \%$ of their contributions if the liable tortfeasor is insolvent. Arguably a lobby is thereby created that may try to unduly influence the decision-making process. Then, it is also doubtful why, when recovery is not possible from a liable tortfeasor, the National Disaster Fund would have to compensate. It is strange that a fund, created to compensate damage caused by natural disasters, would now have to intervene for damage in case of a technological catastrophe. Finally the question also arises to what extent this model provides correct incentives to potential tortfeasors (and their insurers) to avoid insolvency. Rapid claims solutions should therefore also be accompanied by mandatory solvency guarantees when there is a risk of insolvency. To provide effective incentives a fund may never automatically step in, but must remain a clear measure of last resort. That is a problematic aspect of the Belgian Act. The more logical approach (from the perspective of providing incentives for prevention to the tortfeasor) would have been to impose the duty to pre-finance the compensation to the victim upon the tortfeasor and his liability insurer.

On a positive note, tortfeasors will, via recourse actions, still be exposed to the costs of their actions and may hence still have incentives for prevention. Moreover, the victim will always be compensated. For the victim easy access to the system is guaranteed. The costs and obstacles to distributing the losses from the damage payments are not the victim's concern as long as they do not upset the working of the mechanism. Overall, there seem to be only loose requirements on who can obtain how much compensation and under what circumstances. As said, this may leave scope for capture, frivolous complaints and erroneous decisions.

\subsubsection{Conclusion}

Although some criticism can be formulated concerning the specific design of the Belgian compensation model, the solution shows an interesting example of a model where an administrative agency provides (in principle speedy) compensation to victims and subsequently still recovers costs from the tortfeasors. The possibly long procedure to recover the damage from the tortfeasor, his insurer, or the National Disaster Fund, is carried out by the fund after compensation has already been obtained by the victims. Such a model could in principle serve (1) the goal of rapid compensation of victims and (2) the goal of a correct risk allocation to the injurer. To reach the second goal some contingencies in the design would still need to be fine-tuned. If the system worked perfectly it would mean that the victims would be 
compensated as if liability were applicable (which would imply the application of a contributory negligence defense) and the fund would in that particular case only prefinance compensation and later recover this from the liable injurer and his insurer (unless they are insolvent, of course). The fund is designed as an addition to social security and insurance mechanisms rather than as a substitute, which may be desirable in terms of the scope of a rapid claims settlement mechanism. ${ }^{101}$

Although one has to consider that in Belgium, as the Ghislenghien case shows, a criminal procedure, rather than a civil procedure may be the alternative, only at the end of this can compensation payments take place. In Law and Economics literature criminal procedures are considered the most burdensome from the point of view of administrative costs. ${ }^{102}$ Therefore a speedier scheme may be even more welcomed in the specific case of Belgium.

\section{POTENTIAL AND LIMITS OF OUT-OF-COURT RAPID CLAIMS SETTLEMENT}

In the light of the lower administrative costs of an ADR solution as compared with complex tort litigation in court, the goal of this section is to set out the potential and limits of such solutions. Both systems that we discussed are made available to the respective victims as a faster working option to the ordinary liability regime. Both solutions aim at forcing the tortfeasor to eventually pay the compensation to the victims. The tortfeasors will hence still be exposed to the social costs created through their activities. That should hence contribute to achieving the goals of deterrence and compensation

\subsection{The Deterrence Function}

To ensure the deterrence function of tort law, tortfeasors have to be exposed to the social costs of their activities (by allocating the damage to them). Via both systems that we discussed liability is to be allocated to the respective tortfeasor. Furthermore, a fast-working system exposes the operators quickly to the legal consequences and, consequently, ensures fast compliance and helps to deter legal violations. In this sense fast solutions may be particularly beneficial. In the Belgian Fund in fact the fund pre-finances the rapid compensation and later claims back from the liable tortfeasor or his liability insurer. This shows that caution is required. Whereas the situation does herewith not change for the victims, it shows that the probability that the tortfeasor himself will ultimately be held liable may never be reduced or distorted by a burdensome system.

Likewise by increasing access to justice at low costs as both systems achieve it, the deterrent function of tort law may be strengthened as the tortfeasor is in the best case exposed to the full amount at stake. However, the deterrent effect may be lost if the system does not grant the adequate award of damages and, more generally speaking, may handle too little or too many cases. The discussed examples give some

101 Michael Faure and Franziska Weber, 'Security Mechanisms for Insolvencies in the Package Travel Sector' (2013) 36 J Consum Pol 425.

102 Michael Faure, Anthony Ogus and Niels Philipsen, 'Curbing Consumer Financial Losses: the Economics of Regulatory Enforcement’ (2009) 31 L \& P 178. 
insights regarding such questions. They show how the accuracy of the procedure, which would, hence, give the right incentives to potential tortfeasors, can be improved by means of setting out clear criteria and involving the different interest groups in the decision-making process. This can, likewise, decrease the likelihood of error. Frivolous complaints should be identified and rejected by way of such clear procedures and over-deterrence thereby be avoided. From a deterrence point of view injurers should be exposed to the social costs of their activity. It is not required that the payment due by the tortfeasor corresponds exactly to each victim's individual loss. ${ }^{103}$ The US example indicates that the arguably generous offer by BP may potentially have attracted frivolous claims. This danger exists similarly with all alternatives according through which payment would not take place via liability law, but rapidly eg through a government commission, facility or fund, which would not apply the conditions of liability law in the same way as would be done under the court procedure. The important design feature is consequently the extent to which such a system can filter out any unmeritorious cases it attracted with its quick procedure. However, if, within such an alternative scheme like the GCCF, a protocol is drafted with clear eligibility criteria for claimants and criteria for the assessment for damages, the system would very well be able to rule out frivolous and fraudulent claims. A related point is that within the alternative systems full procedural fairness (including the right of claimants to be heard) cannot always be guaranteed. ${ }^{104}$

The Belgian example, but in a way also the GCCF showed that the existence of alternative routes may lead to the advantage of providing victims a choice, but may also create information costs. Victims will indeed have to choose between the speedy award of a standardised amount via $\mathrm{ADR}$ or the chance of full compensation via the slow route of a court procedure). To the extent that the complexity of this choice leads to tortfeasors not being exposed to the full costs of their activity, this could equally negatively affect the incentives for care.

\subsection{The Compensation Function}

When we talk about victim compensation, this can be set in relation to the deterrence goal. The aspect of compensation has an impact on whether the tortfeasor feels a credible deterrent effect of being held liable. At the same time it looks at the interests of the victim. Only those victims who really suffered losses due to the particular incident should be compensated, or expect to be compensated, and then only for the damage resulting from that incident. We have discussed means that are capable of increasing the accuracy of the procedures to ensure this aspect. The interesting feature with the system of rapid claims settlement is that compensation for a certain group of people that would suffer because of a long court procedure comes earlier.

Kaplow and Shavell indicated that as long as on average the damage will be correctly assessed by the courts potential injurers will receive appropriate behavioural incentives even when the assessment of damages in a specific case is not always accurate. See Louis Kaplow and Steven Shavell, 'Accuracy in the Assessment of Damages' (1969) 39 J L Econ 191; Michael Faure and Louis Visscher, 'The Role of Experts in Assessing Damages, Seen from a Law and Economics Perspective' (2011) 3 Eur J Risk Reg 376.

104 In the words of Feinberg: 'Under the circumstance, the right to be heard was at odds with requirements of speed and efficiency': Feinberg (n 34) 165. 
The question, hence, arises as to whether ADR should only be made available for this group of victims or for all victims? In this sense the discussion differs from generally contrasting $\mathrm{ADR}$ and court litigation and weighing their strengths and weaknesses where fast compensation has no particular benefit attached to it. It may not always be an issue. But here, given it is an additional benefit, some costs of ADR may arguably be disregarded or in other words, it is worth regulating them.

In principle it seems that both functions of tort law can also be achieved in the out-of-court system. However, out-of-court solutions are more prone to error (in admitting frivolous cases and coming to wrong decisions) and captured interests of the players involved. Which role should, then, be reserved for civil litigation? We see a particular benefit of $\mathrm{ADR}$ for the share of cases where speed is of essence. The fact that a civil procedure related to a liability case may take a substantial amount of time can also be important to review whether the goals of tort law (deterrence and compensation) are actually served. ${ }^{105}$ The most crucial parameter seems to be the accuracy of the compensation amounts. To an important extent the procedure will need to verify whether the amounts claimed by the victim are indeed correctly representing the loss suffered by the victim (to avoid moral hazard on the victim's side) and whether it is indeed the tortfeasor who caused the loss (to obtain a correct risk allocation to that operator).

\subsection{Conditions for an Effective Rapid Claims Handling Mechanism}

Particular policy considerations are to be taken into account when attempting to develop a rapid claims management system for particular victims regarding the accuracy, the players involved, the interrelation between various systems - all under the benchmark of the goals of tort law. To avoid opportunistic behavior by both the potential tortfeasors and the victims, these mechanisms need to be carefully designed by paying attention to efficient risk differentiation. This implies that tortfeasors need to be exposed to the risk that they create and (in case of multiple tortfeasors) in proportion to their contribution to the accident risk. Close attention needs to be paid to the incentives of victims and enforcers.

This leads to the following guidelines for disaster-based ADR mechanisms. A facility could be created which rapidly pays the damage to a specific category of victims, for which substantial follow-on harm can be prevented, which leads to large societal benefits. Cases would need to be classified as those involving high risk of substantial follow-on damage and those in which time is less of an issue. The ADR mechanism will hence in particular be of importance for cases in which time is of essence. The additional benefit stemming from fast solutions shifts the cost benefit analysis more clearly to $\mathrm{ADR}$ rather than court litigation than in the case of disputes where time is not of essence.

Sufficient funds to finance such a system have to be guaranteed. The first best option is to have the liable tortfeasor himself pre-finance the rapid compensation to the victims (as in the case of the GCCF) to avoid that obstacles in the procedures to take recourse reduce the deterrent effect of the enforcement system. Only when this would be impossible could one imagine pre-financing by the facility (such as in 
Belgium) and an ex post repayment by the liable tortfeasor or his insurer. In Belgium a system involving pre-financing by the collectivity of insurers is in place. As mentioned, this is only the second best option. A model (as in Belgium) based on ex ante financing by the fund needs to ensure that liability will ultimately be allocated to the tortfeasor. Therefore, for example, in a model as in Belgium to the extent that the operator would not have pre-financed the facility, the facility would be subrogated in the rights of the victim, thus claiming back the compensation from the person(s) liable for the incident to create a correct allocation of the risk.

Out-of-court dispute resolution procedures may not only base the decision on legal criteria, but equally on equity considerations. With a view to avoiding that this sets the wrong incentives to tortfeasors, for instance in that they systematically underestimate the probability of needing to pay compensation, the following guideline holds: eligibility of claimants and assessment of damages should in principle take place on the basis of criteria of tort law ${ }^{106}$ to guarantee a correct allocation of the risk to the tortfeasor and to serve compensation goals. In one way or the other a claim verification would need to take place, verifying that under normal rules of tort law those claims would be compensated as well (thus avoiding moral hazard on the side of the victim). However, the example of the GCCF indicated that the marginal benefits of this verification should outweigh its marginal costs. One could imagine a role of the court in the verification process. In that case verification should, however, only be marginal and not include a second guessing of the results obtained by the facility. The latter could lead to additional costs and a loss of the advantages of speed. Given that not all cases but only the urgent cases in which time arguably matters even more than the amount some lighter procedural requirements may apply with a view to the out-of-court solution.

It is crucial that sufficient account is taken of the composition of the entity that will apply the out-of-court solution. This ensures balanced decision-making. Victims may, such as in the US example, be involved in the design of the procedure. In addition to the tortfeasor being exposed to the costs of the harm, one can imagine exposing him (at least to some extent) ${ }^{107}$ to the costs of administering the complaints handling. In such a context it is even more crucial that measures are taken to avoid capture or a bias in the decision-making.

Rather than dealing with all claims in one collective procedure, benefits can be seen in an assessment on a case-by-case basis which guarantees that each victim is satisfied individually. There are various techniques which increase victims' satisfaction with an out-of-court procedure and at the same time mitigate problems of biased decision-making. Victims can, for instance, be involved in the whole process of setting up a compensation mechanism as was done in the case of Deepwater Horizon. One can design procedures in which the victim's side may be involved even more. Additionally one could smartly design appeal options that would increase accuracy and be a tool to control the quality of the decision-making. A case-by-case

106 Which can either be the common law of torts (like in the Belgian case) or a special statue like the US Oil Pollution Act (in the case of the GCCF).

107 An allocation of the full costs of the out-of-court entity to the tortfeasor may equally lead to over-deterrence, which should be avoided as well. 
approach has the inherent advantage that an occurrence and spreading of errors can be avoided to a large extent.

Last, there is a benefit in such a facility being presented as optional in that it allows victims to choose the way that best satisfies their preferences. However, a complex system also entails the danger that victims face a large information costs in finding out the beneficial route. At the same time if many victims opted for the wrong route due to a lack of information, this may again negatively impact the tortfeasoŕs incentives to take optimal care.

\section{CONCLUDING REMARKS}

Many of the evolutions that have taken place in the compensation of victims of disasters via tort law in the past decades have mostly focused on substantive law issues. However, increasingly it has become clear that, especially in the case of mass disasters (involving a large number of claimants) mere changes in substantive law may not suffice. A few cases show that complex litigation can take so long as to substantially increase the victim's losses. Even if, after many years of litigation, victims finally obtain compensation, they may still face bankruptcy or going out of business, as a result of which total social losses would hence be substantially higher than if compensation had taken place earlier. It is therefore no surprise that increasingly the attention has now also shifted to procedural solutions that can guarantee rapid compensation to victims. Those procedural solutions often constitute alternatives to the traditional civil litigation via the court system. As we indicated, it would be too simple to argue that the alternatives to the court system are necessarily always better, both for victims and for society. After all, the time needed to deal with a tort suit also serves as a goal, more particularly a verification of whether particular claimants are eligible under the tort system and whether particular damage can be compensated. To fully appreciate the advantages of an alternative out-of-court system, a careful design of the system is of crucial importance to guarantee that adequate compensation to the victims can be guaranteed as well as a correct allocation of the risk to the tortfeasor. This may include that only a certain share of cases should effectively be filtered to rapid out-of courts solutions. These may be the easy and urgent cases, where fast resolution generated a unique benefit. There may therefore also be some scope to relax some procedural requirements because time is even more of an essence than accuracy. At the same time the body would need to filter out frivolous complaints quickly.

As the two real world examples showed, the devil is often in the detail and an optimal design of such a mechanism remains of utmost importance. The advantages of lower costs and speed come at a price in terms of a reduction of procedural fairness and standardisation of the compensation. One of these questions is whether the facility should be structural (as in Belgium) and thus be in place whenever a (technological) disaster may happen, or rather ad hoc (as in the case of the GCCF). Moreover, the question can equally be asked whether there are comparative advantages in structuring a facility on the basis of $\mathrm{ADR}$ principles (like the GCCF) or along the lines of administrative law (like the Belgian compensation fund). Both issues definitely merit further research. However, the design of the GCCF has the 
major advantage that the liable tortfeasor (in that case BP) directly and ex ante financed the facility, whereas in the Belgian model pre-financing takes place via the collectivity of insurers with only ex post repayment by the liable injurer. This always creates risks of opportunistic behaviour of the particular operator who may become insolvent and then de facto shifts the risk to other operators (and insurers), thus creating an undesirable cross-financing.

The question could equally be asked how the facility should relate to the court system. As a principle matter the system should always remain optional. Victims cannot be denied the right to take their case to court if they wish so. However, one could imagine a role of the court in the verification of the handling of claims by the facility. Such a role should then at most consist of a marginal control to avoid additional costs and a loss of the advantages of speed.

Finally, it may be clear (as the case of the GCCF showed) that one can expect large opposition to those facilities from personal injury lawyers. They will hardly support a system that means a loss of business to them and where (especially if payment takes place on an hourly basis) ${ }^{108}$ a speedy handling of claims is not in their interest either. However, in this case an alliance of potential victim groups and industry could be formed, both gaining from a facility that in the end pays more to the victims than in tertiary costs (more particularly to the plaintiff bar). Such a cost-reduction is ultimately in the interest of society as well.

\section{ACKNOWLEDGEMENTS}

We are grateful to Wenqing Liao and Andrea Rigamonti (Maastricht) for useful research assistance. We wish to thank the participants of the IUCNAEL (IUCN Academy of Environmental Law) 2014 Annual Colloquium, 4 July 2014, in Tarragona and the participants of the EALE (European Association of Law and Economics) Annual Conference 2014, 19 September, in Aix-en-Provence for their useful comments. We are equally grateful to Liz Fisher for excellent comments and editorial revision of an earlier version of our text. 